on asthma prevalence, despite small numbers $(n=158)$, contradicts published findings for this factor but has been studied little.? There has been no mention of the effect of solid fuel fires on asthma in the published reports but in this study a positive association was shown. The significant positive relationship between ducted air heating and wheeze also needs further investigation to confirm the findings of this study. It is important to continue to press for monitoring of and action to reduce air pollutants in relation to the increasing traffic and pollution problems at a time when asthma prevalence is increasing.
1 Strachan DP, Sanders CH. Damp housing and childhood asthma: respiratory effects of indoor air temperature and relative humidity. 7 Epidemiol Community Health $1989 ; 43$ : $7-14$.

2 Fruedenthal PC, Roth HD, Hammerstrom T, et al. Health risks of short-term $\mathrm{SO}_{2}$ exposure to exercising asthmatics. risks of short-term $\mathrm{SO}_{2}$ exposure to exercising asthmatics. Journal

3 Perry GB, Chai H, Dickey DW, et al. Effect of particulate air pollution on asthmatics. Am $\mathcal{F}$ Public Health 1983;73(1):

4 Walters S. Air pollution and respiratory disease. Proceedings of the Royal Society of Medicine Conference 1992. London: Royal Society of Medicine, 1992.

5 Kingham S. Air pollution and respiratory health in Preston a GIS approach. Lancaster: Lancaster University, 1993. Thesis.

6 Alexander L. The leisure activities and health of primary schoo children in coastal Lancashire. Report no. 2. Lancaster: Environmental Epidemiology Research Unit, Lancaster University, 1990.

7 Burr ML, St Leger AS, Yarnell JWG. Wheezing, dampness, and coal fires. Community Med 1981;3:205-9.

\title{
Social network and lifestyle in Danish adults
}

\author{
Merete Osler
}

Several prospective studies have associated restricted social network with increased mortality and morbidity, and have increased interest in the possible relations between social network and lifestyle. ${ }^{1-3}$ This study analyses associations between social network and lifestyle - in this case leisure activity, smoking, and the intake of vegetables.

Methods: Data were collected by questionnaire in 1987-88 in a five year follow up study of a random sample $(n=3608)$ of men and women aged $35,45,55$, and 65 years, and living in the County of Copenhagen, Denmark. A total of 2987 participated in the study. Additional information on non-participation and the method of data collection have been reported elsewhere. ${ }^{4}$ Both subjectively perceived and more objective aspects of social network were measured by six variables: (1) contact frequency with family or (2) with friends, neighbours, and relatives; (3) involvement in community activities; (4) marital status; (5) emotional support reflecting the opportunity for talking to intimate relatives and friends about personal matters; and (6) social support describing the person's satisfaction with access to social support when feeling lonely.

Odds ratios (OR) and $95 \%$ confidence intervals $(95 \% \mathrm{CI})$ were calculated to investigate the associations between lifestyle and social network. Because both social network and lifestyle varied with age and social class, ${ }^{4}$ these two variables were treated as covariates. Only minor changes of the associations were noted, however, and the unadjusted ORs are presented.

Results: The prevalence of no leisure activity, smoking, and no daily intake of vegetables in relation to social network is shown in the table. In both men and women, the prevalence of no leisure activity was higher in those with infrequent social contacts with friends or those who experienced little social support than in more socially integrated groups. Men living alone or who reported little emotional support were also more often inactive during leisure time. In women, smoking prevalence was higher in those with infrequent social contacts and little social or emotional support than in those who were more socially integrated. In men, smoking prevalence was independent of the social network. Men and women with infrequent contact with friends or little social support ate vegetables less frequently than those who were more integrated socially. In men, no daily intake of vegetable was also related to little emotional support or living singly.

Discussion: This study corroborates reported results of new determinants associated with health related behaviour. Compared with socially integrated men, those with few social contacts or little social support were more often inactive during leisure time and did not eat vegetables every day. Women with few contacts with friends and relatives were more often physically inactive or smokers. In the Alameda county study, ${ }^{1}$ men and women with the fewest social connections were more often smokers and physically inactive than those with the greatest number of connections (estimated by a score based on marital status, contact with friends and relatives, church membership, and membership of other groups). Other studies have reported that married women are less likely to be smokers than unmarried women, and in a recent study of elderly Swedish men, aspects of social isolation were associated with 
Prevalence of no leisure activity, smoking, and no daily intake of vegetables in various categories of social network in Danish men and women, 1987-88

\begin{tabular}{|c|c|c|c|c|c|c|}
\hline & \multicolumn{2}{|c|}{$\begin{array}{l}\text { No leisure activity } \\
\% \quad O R(95 \% \text { CI })\end{array}$} & \multicolumn{2}{|c|}{ Smoking } & \multicolumn{2}{|c|}{$\begin{array}{l}\text { No daily vegetable intake } \\
\% \quad \operatorname{OR}(95 \% \mathrm{CI})\end{array}$} \\
\hline $\begin{array}{l}\text { Men }(n=1524) \\
\text { Contact frequency with family }\end{array}$ & 22 & & 51 & & 72 & \\
\hline $\begin{array}{l}\text { High }(n=899) \\
\text { Low }^{*}(n=625)\end{array}$ & $\begin{array}{l}20 \\
26\end{array}$ & $1 \cdot 3(1 \cdot 1,1 \cdot 7)$ & $\begin{array}{l}49 \\
53\end{array}$ & $1.2(1.0 \quad 1.5)$ & $\begin{array}{l}71 \\
75\end{array}$ & $1.2(0.015)$ \\
\hline $\begin{array}{l}\text { Low* }(n=457) \\
\text { Community involvement }\end{array}$ & $\begin{array}{l}19 \\
30\end{array}$ & $1.9(1.5,2.4)$ & $\begin{array}{l}51 \\
50\end{array}$ & $1 \cdot 0(0 \cdot 8,1 \cdot 2)$ & $\begin{array}{l}70 \\
75\end{array}$ & $1 \cdot 3(1 \cdot 0,1 \cdot 7)$ \\
\hline $\begin{array}{c}\text { High }(n=280) \\
\text { Lowt }(n=1236) \\
\text { Marital status }\end{array}$ & $\begin{array}{l}19 \\
23\end{array}$ & $1 \cdot 3(0.9,1.8)$ & $\begin{array}{l}45 \\
52\end{array}$ & $1 \cdot 3(1 \cdot 0,1 \cdot 7)$ & $\begin{array}{l}69 \\
73\end{array}$ & $1 \cdot 2(0.9,1.6)$ \\
\hline $\begin{array}{l}\text { Cohabiting }(n=1295) \\
\text { Single }(n=229)\end{array}$ & $\begin{array}{l}21 \\
29\end{array}$ & $1 \cdot 5(1 \cdot 1,2 \cdot 1)$ & $\begin{array}{l}51 \\
53\end{array}$ & $1.1(0.8,1.4)$ & $\begin{array}{l}71 \\
81\end{array}$ & $1 \cdot 7(1 \cdot 2,2 \cdot 4)$ \\
\hline Emotional support & & $1.11,2.1)$ & & $1.1(0.0,1.4)$ & & $1 \cdot 7(1 \cdot 2,2 \cdot 4)$ \\
\hline $\begin{array}{l}\text { High }(n=1430) \\
\text { Low } \ddagger(n=91) \\
\text { Social support }\end{array}$ & $\begin{array}{l}21 \\
37\end{array}$ & $2 \cdot 1(1 \cdot 4,3 \cdot 4)$ & $\begin{array}{l}51 \\
53\end{array}$ & $1 \cdot 1(0 \cdot 7,1 \cdot 7)$ & $\begin{array}{l}72 \\
85\end{array}$ & $2 \cdot 3(1 \cdot 2,4 \cdot 1)$ \\
\hline $\begin{array}{l}\text { High }(n=1447) \\
\text { Low }(n=70)\end{array}$ & $\begin{array}{l}22 \\
29\end{array}$ & $1.5(0.9,2 \cdot 5)$ & $\begin{array}{l}51 \\
49\end{array}$ & $0.9(0.6,1.5)$ & $\begin{array}{l}72 \\
83\end{array}$ & $1.8(1.0,3 \cdot 5)$ \\
\hline $\begin{array}{l}\text { Women }(n=1463) \\
\text { Contact frequency with family }\end{array}$ & 28 & & 45 & & 57 & \\
\hline $\begin{array}{l}\text { High }(\mathrm{n}=1053) \\
\text { Low }^{*}(\mathrm{n}=410)\end{array}$ & $\begin{array}{l}27 \\
31\end{array}$ & $1 \cdot 2(0.9,1 \cdot 6)$ & $\begin{array}{l}42 \\
47\end{array}$ & $1 \cdot 2(1 \cdot 0,1 \cdot 5)$ & $\begin{array}{l}57 \\
57\end{array}$ & $1 \cdot 0(0 \cdot 8,1 \cdot 3)$ \\
\hline $\begin{array}{l}\text { Contact frequency with friends } \\
\text { High }(n=1024)\end{array}$ & 23 & & 41 & & 56 & \\
\hline $\begin{array}{l}\mathrm{Low}^{*}(\mathrm{n}=430) \\
\text { Community involvement }\end{array}$ & 38 & $2 \cdot 0(1 \cdot 5,2 \cdot 3)$ & 50 & $1.4(1 \cdot 1,1 \cdot 8)$ & 61 & $1 \cdot 2(1 \cdot 0,1 \cdot 5)$ \\
\hline $\begin{array}{l}\text { High }(n=204) \\
\text { Lowt }(n=1258) \\
\text { Marital status }\end{array}$ & $\begin{array}{l}24 \\
28\end{array}$ & $1.3(0.9,1.8)$ & $\begin{array}{l}40 \\
44\end{array}$ & $1 \cdot 2(0.9,1 \cdot 6)$ & $\begin{array}{l}53 \\
58\end{array}$ & $1 \cdot 2(0.9,1 \cdot 7)$ \\
\hline $\begin{array}{l}\text { Cohabiting }(n=1141) \\
\text { Single }(n=322)\end{array}$ & $\begin{array}{l}28 \\
26\end{array}$ & $0.9(0.7,1.2)$ & $\begin{array}{l}43 \\
47\end{array}$ & $1.8(0.9,1.5)$ & $\begin{array}{l}56 \\
60\end{array}$ & $1.2(0.9,1.5)$ \\
\hline $\begin{array}{c}\text { Emotional support } \\
\text { High }(n=1392) \\
\text { Low }(n=70)\end{array}$ & $\begin{array}{l}27 \\
36\end{array}$ & $1.5(0.9,1.8)$ & $\begin{array}{l}43 \\
59\end{array}$ & $1.8(1.1,3.0)$ & $\begin{array}{l}58 \\
49\end{array}$ & $0.7(0.4,1.1)$ \\
\hline $\begin{array}{l}\text { Social support } \\
\text { High }(n=1396) \\
\text { Low } \leqq(n=64)\end{array}$ & $\begin{array}{l}27 \\
39\end{array}$ & $1 \cdot 7(1.0,2 \cdot 9)$ & $\begin{array}{l}43 \\
58\end{array}$ & $1.8(1.1,3.0)$ & $\begin{array}{l}57 \\
71\end{array}$ & $1.9(1.1,3.4)$ \\
\hline
\end{tabular}

$\mathrm{OR}(95 \% \mathrm{CI})=$ odds ratio $(95 \%$ confidence intervals)

* Contact less than 2 times a week; tnot a member of any organizations or attending meetings less than once a year; $\neq$ feeling lonely several times a week; lno intimate relatives or friends to talk with about personal matters.

smoking, physical inactivity, and an unhealthy diet. ${ }^{3}$ In an Australian survey, elderly married men generally had a better diet than men living alone. On the other hand, largely similar patterns and equal or greater nutrient intakes were found in women living alone compared with married women. Epidemiological data also suggest that eating alone leads to less regular meals, to using "fast" food more often, and to reducing the amount and variety of food. ${ }^{5}$

There seem to be different levels of interrelationship between social network and lifestyle, a practical straightforward relationship, the traditional gender role, and the more psychological or behavioural aspects. Practical help from others with shopping or food preparation may have an impact on dietary habits, especially in middle aged men, because in this age group female gender is strongly connected with cooking skills. Some authors have commented extensively on the psychosocial deficit produced by social isolation and its depressing influence which results in reduced activity and less varied food intake. ${ }^{5}$ Studies also suggest that smoking is a way of relieving psychosocial stress, especially in young women. This may explain the association between social isolation and smoking found in the present study. Others have claimed that isolation reduces motivation - for example to quit smoking - as one is not motivated by direct request from others, by deeply felt desires of others, or by concern for the family. Social contacts and support are also important for activity, skills learning, and maintenance of change which are important steps in the process of behavioural change.

It seems probable that family and friends, by their mere presence in the individual's social environment, and the person's own feeling about being alone may have an impact on his or her health related behaviours.

This study was funded by the Danish Heart Foundation, the Health Development Fund (5910-5/16-92), the Health Insurance Fund (11/015-92), the Danish Health Research Council (12-0758-1), and the Danish Medical Association's Research Foundation.

1 Berkman LF, Syme SL. Social networks, host resistance and mortality: a nine-year follow-up study of Alameda county residents. Am ₹ Epidemiol 1979;109:186-204.

2 House JS, Landis KR, Unberson D. Social relationship and ouse JS, Landis KR, Unberson

Hanson BS, Isacsson S-O. Social network, social support and regular leisure-time physical activity in elderly men. and regular leisure-time physical activity in eld

4 European fournal of Public Health 1992;2:16-23. A longitudinal study. Public Health 1993;17:251-60.

5 Schlettwein-Gsell D, dePrins L, Ferry M. Lifestyle: marital status, education, living situation, social contacts, personal habits (smoking, drinking). Eur f Clin Nutr 1991;45(suppl 3):153-68. 